\title{
The Influence of Capital Structure, Profitability and Company Size Towards Manufacturing Company The Pharmaceutical Sector Value of Idx Period of 2012-2015
}

\author{
Chytra Setyawardani Sukamto*, Muhammad Laras Widyanto, Helsinawati
}

Economic and Business Faculty, Universitas Mercu Buana

\section{*Corresponding Author}

Chytra Setyawardani Sukamto

\author{
Article History \\ Received: 08.08.2019 \\ Accepted: 16.08 .2019 \\ Published: 30.09 .2019
}

\begin{abstract}
This study aims to determine the influence of Capital Structure which is limited by Debt to Equity Ratio, Profitability which is limited by Return on Equity (ROE), and Company Size to Company Value (Price to Book Value). The object of this research is pharmaceutical subsector company period 2012 - 2015. The data used is secondary data obtained through Indonesia Stock Exchange. The research design used is causal research. The sampling technique used purposive sampling method. From the method obtained 7 companies that meet the criteria of a total of 11 companies during the four-year observation period. The analysis technique used is panel data regression analysis wirh t-statistic test. The results of this study are Retrun on Equity (ROE) has a positive and significant influence on Price to Book Value, but Debt to Equty Ratio (DER) has a negative and not significant influence on Price to Book Value, and Company Size (Size) has a negative and not significant influence on Price to Book Value of pharmaceutical industry companies listed on the Indonesia Stock Exchange (BEI) in period 2012-2015.
\end{abstract}

Keywords: Debt to Equity Ratio (DER), Return on Equity (ROE), Size, and Corporate Value

\section{INTRODUCTION}

The pharmaceutical sector in 2015 recorded a significant investment commitment growth of $118 \%$ reaching Rp. 6.5 trillion from the previous year's position of Rp. 3 trillion. This amount was obtained from the estimated FDI of US \$105.8 million (around Rp. 1.4 trillion with the exchange rate per US dollar of Rp. 13,900) and from PMDN of Rp. 5.1 trillion. The pharmaceutical sector is also included in the sector which is expected to be developed marked by the government's steps to revise the business sector that becomes more open.

Competition in the manufacturing industry makes every manufacturing company increasingly needs to be obtained permanently. One goal is to maximize the prosperity of shareholders through added value of the company [1]. Researches related to capital structure conducted by Meidiawati [2], prove the capital structure that supports corporate value. Likewise with the research conducted by Prastuti [3], proving that the capital structure has a positive and significant influence on firm value. While the research by Languju [4], proves that the capital structure is not significant towards firm value.

Profitability ratio is a company earning profit in sales, the total can be bought with its own capital [1]. In this study, the profit ratio is assessed by return on equity $(\mathrm{ROE})$. Return on equity $(\mathrm{ROE})$ is a ratio that shows the company's great ability to generate net income to increase equity against shareholders.

Research conducted by Repi [5], variable profitability as measured by Return On Equity (ROE). The results of his research show that ROE simultaneously has a significant influence on firm value. While the research conducted by Manoppo [6] (2016), profitability as measured by Return On Equity (ROE), shows that Return On Equity (ROE) does not influence the value of the company. As well as research conducted by Warouw [7], where simultaneous Return On Equity (ROE) has an influence but not significantly on firm value but, partially Return On Equity (ROE) has no relationship to firm value.

Copyright @ 2019: This is an open-access article distributed under the terms of the Creative Commons Attribution license which permits unrestricted use, distribution, and reproduction in any medium for non commercial use (NonCommercial, or CC-BY-NC) provided the original author and source are credited. 
The size of the company is considered able to influence the value of the company. Because the larger the size or scale of the company, the easier it will be for the company to obtain funding sources both internal and external. Research conducted by Rudangga [8], company size was stated to have a positive influence on firm value. But the size of the company has a negative and not significant influence on the value of the company by Rumondor [9]. Likewise with the research conducted by Pantow [10], where the size of the company has a negative and insignificant influence on firm value. The better the company able to manage the intellectual capital, the better the value of Retir on Assets (ROA) [11]. Current Ratio, Debt to Equity Ratio, Return on Equity and Total assets Turn over simultaneously is weak and not significant to Capital Gains [12].

The inconsistency of the results of some of the above studies provides motivation to re-examine the influence of capital structure, profitability and firm size on different time dimensions (2012 - 2015).

Thus the purpose of this study is to determine the influence of: (1) Capital structure that is limited by the Debt to Equity Ratio (DER) to the value of the pharmaceutical industry companies listed on the Indonesia Stock Exchange for the period 2012-2015; (2) Profitability is limited by Return on Equity (ROE) on the value of pharmaceutical industry companies listed on the Indonesia Stock Exchange for the period 2012-2015; (3) The size of the company against the value of the pharmaceutical industry companies listed on the Indonesia Stock Exchange for the period 2012-2015.

\section{Materials And Method}

The value of the company. Husnan [13] defines the value of the company or also called the market value of the company is the price that the prospective buyer is willing to pay if the company is sold. Company value can be seen through the market value or book value of the company from its equity. Market value is the stock price that occurs on the stock market and is determined by market participants at a certain time. The stock price always changes every day even if the stock price changes every second. Therefore, market participants must be able to pay attention to the factors that influence stock prices. The main objective of the company is to maximize profits or wealth, especially for its shareholders, in the form of efforts to increase or maximize market value for the company's share price.

According to Prasetia et al. [14], the general ratio used to view loan comparisons from creditors both used as additional capital and sources of funds for purchases requires a loan ratio that is seen from the capital structure, namely Debt to Equity Ratio.Harahap [15] DER is a ratio capital determined to which owner's capital can be accounted for - debt to external parties and is a ratio that measures up to where the company is financed from the loan. This ratio is also called the leverage ratio. The formula used to calculate the debt to equity ratio is as follows Prastowo and Julianty [16]:

$$
\text { Debt to Equity Ratio }(D E R)=\frac{\text { Total Debt }}{\text { Total Equity }} \times 100 \%
$$

Profitability. According to Hanafi [17], profitability ratios are ratios that determine a company's ability to generate net income at the level of sales, certain assets and capital shares. This ratio is reflected in Return On Equity (ROE). ROE is a ratio for calculating net income obtained with own capital. This ratio shows the efficiency of the use of own capital. The higher the ratio, the better. Contradicting the position of the company owner is getting stronger, and vice versa [18].

$$
\text { Return On Equity }(R O E)=\frac{\text { Earning After Tax }}{\text { Total Equity }} \times 100 \%
$$

Can help deny that profitability is a company that produces profits in the number of sales, the total amount that is responsible for its own capital to generate net income at the level of sales, certain assets and capital.

The following calculation formula ROE by Gitman and Zutter [19] as follows

$$
\text { Return On Equity }(R O E)=\frac{\text { Earning After Tax }}{\text { Total Equity }} \times 100 \%
$$

Company Size. Company size is seen from the total assets allocated by the company that can be used for company operations [18]. The size of the company (Size) is received with the natural log of the total received. Formula of the following company sizes:

$$
\text { Size }=L N \text { of total assets }
$$

previous Research:1. Capital structure in the research conducted by Languju [4] with the research title Influence of Return On Equity, Company Size, Price Earning Ratio and Capital Structure Against the Value of Property And Real Estate Companies Listed on the Indonesia Stock Exchange, concludes that capital structure has no significant influence against the value of the company. 
2. Profitability in the research conducted by Repi [5] with the research title Factors Influenceing the Corporate Value of the Banking Subsector at the IDX in Facing MEA, and Profitability in research conducted by Rasyid [20] entitled Influences of ownership structure, capital structure, profitability and company growth towards firm value, which of these two studies says that ROE has an influence on firm value.

3. Company Size in a study conducted by Rumondor [9] with the title of research on the Influence of Capital Structure, Company Size and Corporate Risk on Firm Value in the Plastic and Packaging Sub Sector on the IDX, and Company Size in a study conducted by Pantow [10] with the title of the study is Analysis of Sales Growth, Company Size, Return On Assets, and Capital Structure Against Company Values Recorded in the LQ 45 Index, which of the two studies says that Size has no influence on firm value.

\section{Framework of thinking}

The thinking framework in this study can be seen in the picture below:

Figure 1 Framework for Conceptual Thinking

Research Hypothesis:

$\mathrm{H}_{1}$ : It is assumed that the debt to equity ratio (DER) variable has a significant influence on the value of pharmaceutical companies listed on the Indonesia Stock Exchange for the period of 2012 - 2015.

$\mathrm{H}_{2}$ : It is assumed that the return on equity (ROE) variable has a significant influence on the value of pharmaceutical companies listed on the Indonesia Stock Exchange for the period of 2012 - 2015.

$\mathrm{H}_{3}$ : It is assumed that the Size Size variable has a significant influence on the value of pharmaceutical companies listed on the Indonesia Stock Exchange for the period of 2012 - 2015.

The research method used in this study is a causal research method. Where this method is done to determine the influence of one or more independent variables on certain variables. In this study, the influences of DER, ROE, and Size (independent variables) on firm value (dependent variable) were examined.

The population used in this study is a pharmaceutical company registered on the Stock Exchange in the period $2012-2015$ with a total of 11 companies. The sample in this study was conducted using a purposive sampling technique, as many as 7 companies that met the criteria for receiving data. The data used in this study is secondary data that contains financial report data, approved financial statements, and company fact books that are supported. Data is obtained from the Indonesia Stock Exchange (www.idx.co.id).

Variable. The variable used in this measurement scale is the ratio. The variables needed are:

Debt to Equity Ratio (DER) is the ratio of capital loans that must be paid on the basis of the owner's capital that can be accounted for - loans to external parties and is a measured ratio based on where the company is financed from the loan.

Return on Equity (ROE) is the ratio for measuring net income after tax with own capital. This ratio shows the efficiency of the use of own capital.

The size of the company for large-scale companies is generally easier to obtain from small companies because it is related to the level of creditor trust in large companies.

Company value equal to the value of future profits will be exploited which is recalculated with the right interest rate.

Data analysis technique. The technique is done by grouping data based on the variables and types of respondents, tabulating data based on variables from all respondents, giving data for each variable collected, calculating to answer the problem, and calculating to test the hypothesis that has been proposed.

Descriptive Statistics Analysis. Descriptive statistical analysis in this study included the characteristics of pharmaceutical companies that were the samples of this study. In addition, variable depictions were also completed with the average, maximum, minimum, and standard deviation of each variable used in the analysis.

Stationary Data Test. This trial was conducted to study whether the research data used was stationary or not.

Chow Test. This test is done to select the method used is the method of Common Influence or Fixed effect [21]. 
Hausman Test. This test compares the fixed effect model with the random effect method in determining the best model to be used as a panel data regression model [21]. The Lagrange Multiplier Test (LM Test). Lagrange Multiplier (LM) is a test to determine whether the Random effect model or Common Influence (OLS) model is the most appropriate to use [22].

Test the Panel Data Regression Model (Test F). The F test is conducted to determine whether the independent variables used in the research model have simultaneous influence on the dependent variable. In this study the independent variables are DER, ROE, and Size while for the independent variable is the firm value (PBV). Hypothesis: $H_{0}$ is accepted if the probability of the level of significance Fcount $>a=0.05$ and $\mathrm{H}_{0}$ is rejected if the probability of the level of significance Fcount $<\alpha=0.05$. Assumption: $\mathrm{H}_{0}$ is accepted, so this shows that the independent variable does not have a significant relationship with the dependent variable and vice versa and $\mathrm{H}_{0}$ is rejected, so this indicates that the independent variable has a significant relationship with the dependent variable.

Panel Data Regression Coefficient ( $t$ Test). To determine the influence of each variable, the test used is the t test. The $t$ test is used to test between the dependent variables, namely the value of the company with each independent variable in this study, namely DER, ROE, and Size at the significance level of $5 \%(0.05)$ partially. The hypothesis used in this study uses the partial $t$ test and the hypothesis as follows: $\mathrm{H}_{1}$ : It is assumed that there is an influence and significant Debt to Equity Ratio (DER) on the value of the pharmaceutical industry company in 2012-2015; $\mathrm{H}_{2}$ : It is assumed that there is influence and significant Return On Equity (ROE) on the value of the pharmaceutical industry in 2012-2015; and $\mathrm{H}_{3}$ : It is suspected that there are significant and significant influences on the value of the pharmaceutical industry in 2012-2015.

\section{RESULTS AND Discussion The Result of Statistic Test}

The Result of Statistic Test as follows

Table-1: Chow Test

\begin{tabular}{|c|c|c|c|}
\hline \multicolumn{4}{|c|}{ Redundant Fixed Effect Test } \\
\hline \multicolumn{4}{|l|}{ Equation: FIXED EFFECT } \\
\hline \multicolumn{4}{|c|}{ Test cross-section fixed effects } \\
\hline Influences Test & Statistic & d.f. & Prob. \\
\hline Cross-section F & 6.842642 & $(6,18)$ & 0.0007 \\
\hline Cross-section Chi-square & 33.267133 & 6 & 0.0000 \\
\hline
\end{tabular}

Based on the results of the Chow test it can be seen that the hypothesis value has a prob value. $F$ which is smaller than a $(0.05)$ is 0,0007 so that $\mathrm{HO}$ is rejected and used instead of Common Influence, it means that it must proceed to the Hausman test to see the suitable method used whether using Random effect Model or Fixed effect Model.

Table-2: Hausman Test

\begin{tabular}{|c|c|c|c|}
\hline \multicolumn{3}{|c|}{ Correlated Random effects - Hausman Test } & \\
\hline \multicolumn{3}{|l|}{ Equation: Random effects } & \\
\hline \multicolumn{3}{|c|}{ Test cross-section random effects } & \\
\hline Test Summary & $\begin{array}{l}\text { Chi-Sq. } \\
\text { Statistic }\end{array}$ & Chi-Sq. d.f. & Prob. \\
\hline Cross-section random & 6.225349 & 3 & 0.1011 \\
\hline
\end{tabular}

Based on the results of the Hausman test it can be seen that the probability results are 0.1011 which means that the value is greater than a which is 0.05 so that $\mathrm{HO}$ is accepted which means the model used is the Random effect Model. Because from the Hausman test results show that Random effect Model is the right model. 
Table-3: Random effect Model

\begin{tabular}{|c|c|c|c|c|}
\hline \multicolumn{5}{|c|}{ Dependent Variable: Price to Book Value } \\
\hline \multicolumn{5}{|c|}{ Method: Panel EGLS (Cross-section random effects) } \\
\hline \multicolumn{5}{|c|}{ Date: 09/09/17 Time: 10:24 } \\
\hline \multicolumn{5}{|l|}{ Sample: 20122015} \\
\hline \multicolumn{5}{|l|}{ Periods included: 4} \\
\hline \multicolumn{5}{|c|}{ Cross-sections included: 7} \\
\hline \multicolumn{5}{|c|}{ Total panel (balanced) observations: 28} \\
\hline \multicolumn{5}{|c|}{ Swamy and Arora estimator of component variances } \\
\hline Variable & Coefficient & Std. Error & t-Statistic & Prob. \\
\hline C & 1.877247 & 1.107327 & 1.695296 & 0.1030 \\
\hline DER & -0.614370 & 1.080009 & -0.568856 & 0.5747 \\
\hline ROE & 0.166795 & 0.033716 & 4.947111 & 0.0000 \\
\hline \multirow[t]{3}{*}{ SIZE } & -0.047622 & 0.064899 & -0.733776 & 0.4702 \\
\hline & \multicolumn{2}{|c|}{ Influences Specification } & & \\
\hline & & & S.D. & Rho \\
\hline \multicolumn{3}{|l|}{ Cross-section random } & 0.932430 & 0.5255 \\
\hline \multicolumn{3}{|l|}{ Idiosyncratic random } & 0.885942 & 0.4745 \\
\hline & \multicolumn{2}{|c|}{ Weighted Statistics } & & \\
\hline R-squared & 0.568264 & \multicolumn{2}{|c|}{ Mean dependent var } & 1.538357 \\
\hline Adjusted R-squared & 0.514297 & \multicolumn{2}{|c|}{ S.D. dependent var } & 1.353945 \\
\hline S.E. of regression & 0.943597 & \multicolumn{2}{|c|}{ Sum squared resid } & 21.36899 \\
\hline F-statistic & 10.52985 & \multicolumn{2}{|c|}{ Durbin-Watson stat } & 2.213090 \\
\hline \multirow[t]{2}{*}{ Prob(F-statistic) } & 0.000131 & & & \\
\hline & \multicolumn{2}{|c|}{ Unweighted Statistics } & & \\
\hline R-squared & 0.733886 & \multicolumn{2}{|c|}{ Mean dependent var } & 3.585000 \\
\hline Sum squared resid & 49.89739 & \multicolumn{2}{|c|}{ Durbin-Watson stat } & 0.947775 \\
\hline
\end{tabular}

Testing the Data Panel Regression Model. Based on the results of testing the model using Random effect, it is obtained that the F-statistic value is 10.52985 with the probability of F-statistic 0.000131 which means that it is smaller than the significance level of $0.05(5 \%)$, this means that $\mathrm{HO}$ is rejected. This means that in this study there are independent variables that have a significant influence on the dependent variable, namely the value of the company. Based on t test are Debt to Equty Ratio (DER) has a negative and not significant influence on Price to Book Value,Retrun on Equity (ROE) has a positive and significant influence on Price to Book Value, Company Size (Size) has a negative and not significant influence on Price to Book Value,

\section{Discussion Relationships with Prior Research}

Influence of Capital Structure on Company Values. Based on the results of statistical tests show that the capital structure variable does not influence the value of the company, this study supports the research conducted by Languju [4] that in his research it is in line with the theory of modigliani and miller (MM) approaches which argue that capital structure is irrelevant or not influence the value of the company.

Influence of Profitability on Company Values. Based on the results of statistical tests showing that the profitability variable has a positive and significant influence on firm value, the research that supports this research is Repi [5] and Rasyid [20] which from both of these studies say that ROE has an influence on firm value. The results of this test can show that the higher the profitability, the company can generate high profits for shareholders, so that it will make investors interested in investing in shares of the company that provide large profits to shareholders.

Influence of Size on Company Values. Based on the results of statistical tests showing that the Size variable does not influence the value of the company, the research that supports this research is Rumondor [9] and Pantow [10], which of the two studies says that Size has no influence on firm value. This means that the decrease in the value of the company size does not significantly influence the increase in firm value. These results become a phenomenon when compared with existing theories are the size of the company will have a positive influence on the value of the company. It is assumed that investors buy shares without looking at or considering the size of the company, especially because the object of this research is pharmaceutical companies, some of which have health products that are widely known to the public. 


\section{CONCLUSION AND SUgGESTION \\ Conclusion}

Based on the results of research that has been conducted on the influence of Capital Structure, Profitability, and Company Size on the Value of the Pharmaceutical Industry Companies Listed on the Indonesia Stock Exchange (BEI) for the period 2013-2015, the results of this study are Retrun on Equity (ROE) has a positive and significant influence on Price to Book Value, but Debt to Equty Ratio (DER) has a negative and not significant influence on Price to Book Value, and Company Size (Size) has a negative and not significant influence on Price to Book Value.

\section{Suggestion.}

Based on the conclusions and limitations of this study, some suggestions can be conveyed, namely: (1) Future research is expected to develop research with other factors that influence the value of the company outside of this research; (2) Add a sample that includes all companies listed on the Indonesia Stock Exchange so that the results can reflect the company's condition in general.

\section{REFERENCES}

1. Sartono, A. (2010). Manajemen Keuangan Teori dan Aplikasi. Edisi ke4. Yogyakarta: BPFE

2. Prastuti, N. K. R., \& Sudiartha, I. G. M. (2016). Pengaruh struktur modal, kebijakan dividen, dan ukuran perusahaan terhadap nilai perusahaan pada perusahaan manufaktur. E-Jurnal Manajemen, 5(3).

3. Meidiawati, K., \& Mildawati, T. (2016). Pengaruh Size, Growth, Profitabilitas, Struktur Modal, Kebijakan Dividen Terhadap Nilai Perusahaan. Jurnal IImu dan Riset Akuntansi, 5(2), 1-16.

4. Languju, O. (2016). Pengaruh Return On Equity, Ukuran Perusahaan, Price Earning Ratio dan Struktur Modal Terhadap Nilai Perusahaan Property And Real Estate Terdaftar Di Bursa Efek Indonesia. Jurnal Berkala Ilmiah Efisiensi, 16(2).

5. Repi, S., Murni, S., \& Adare, D. (2016). Faktor-faktor yang mempengaruhi nilai perusahaan subsektor perbankan pada BEI dalam menghadapi MEA. Jurnal EMBA: Jurnal Riset Ekonomi, Manajemen, Bisnis dan Akuntansi, 4(1).

6. Manoppo, H., \& Arie, F. V. (2016). Pengaruh Struktur Modal, Ukuran Perusahaan dan Profitabilitas Terhadap Nilai Perusahaan Otomotif yang Terdaftar di Bursa Efek Indonesia Periode 2011-2014. Jurnal EMBA: Jurnal Riset Ekonomi, Manajemen, Bisnis dan Akuntansi, 4(2).

7. Warouw, C. (2016). Pengaruh Perputaran Modal Kerja Dan Profitabilitas Terhadap Nilai Perusahaan Pada Perusahaan Farmasi di Bursa Efek Indonesia. Jurnal Berkala Ilmiah Efisiensi, 16(2).

8. Rudangga, I. G. N. G., \& Sudiarta, G. M. (2016). Pengaruh Ukuran Perusahaan, Leverage, Dan Profitabilitas Terhadap Nilai Perusahaan. E-Jurnal Manajemen, 5(7).

9. Rumondor, R., Mangantar, M., \& Sumarauw, J. S. (2015). Pengaruh struktur modal, ukuran perusahaan dan risiko perusahaan terhadap nilai perusahaan pada sub sektor plastik dan pengemasan di BEl. Jurnal EMBA: Jurnal Riset Ekonomi, Manajemen, Bisnis dan Akuntansi, 3(3).

10. Pantow, M. S. R., Murni, S., \& Trang, I. (2015). Analisa Pertumbuhan Penjualan, Ukuran Perusahaan, Return On Asset, dan Struktur Modal Terhadap Nilai Perusahaan yang Tercatat di Indeks LQ 45. Jurnal EMBA: Jurnal Riset Ekonomi, Manajemen, Bisnis dan Akuntansi, 3(1).

11. Kurniasih, A., \& Heliantono, H. Intellectual Capital Bank Bumn Terbuka Dan Pengaruhnya Terhadap Kinerja Perusahaan. MIX: Jurnal IImiah Manajemen, 6(2).

12. Wahyuni, I., \& Djamaluddin, S. (2016). Pengaruh Kinerja Keuangan Terhadap Kapital Pada Industri Properti di Bursa Efek Indonesia (Periode 2008-2013), Jurnal Imiah Manajemen dan Bisnis. Prodi Manajemen Unversitas Mercu Buana, 2(1), 531-548.

13. Husnan, S., \& Pudjiastuti, E. (2004). Dasar-dasar manajemen keuangan. Yogyakarta: UPP AMP YKPN.

14. Tommy, P., \& Saerang, I. S. (2014). Struktur Modal, Ukuran Perusahaan Dan Risiko Perusahaan Terhadap Nilai Perusahaan Otomotif Yang Terdaftar Di Bei. Jurnal EMBA: Jurnal Riset Ekonomi, Manajemen, Bisnis dan Akuntansi, 2(2).

15. Harahap, S. S. (2008). Analisis Kritis atas laporan keuangan, edisi pertama. Raja Grafindo Persada. Jakarta.

16. Prastowo, D., \& Julianty, R. (2010). Analisa Laporan Keuangan; Konsep dan Aplikasi Edisi Revisi. Yogyakarta: YKPN.

17. Hanafi, M. (2007). Mamduh dan Halim. Abdul, Analisis Laporan Keuangan, Edisi Ketiga, UPP STIM YKPN, Yogyakarta.

18. Hanafi, M. M. (2016). Manajemen Keuangan. Edisi Kedua, Cetakan Pertama.

19. Hirschey, M., Pappas, J. L., \& Whigham, D. (1996). Managerial economics. Dryden Press.

20. Rasyid, A. (2015). Effects of ownership structure, capital structure, profitability and company's growth towards firm value. International Journal of Business and Management Invention, 4(4), 25-31.

21. Widoatmodjo, A. (2001). Ekonomitrika: Teori dan Aplikasi untuk EkonomiBisnis. Yogyakarta: Ekonisia.

22. Gujarati, D. N., \& Porter, D. C. (2012). Dasar-Dasar Ekonometrika, Edisi 5. Jakarta: Salemba Empat.

23. Bursa Efek Indonesia. (2016). www.idx.co.id 